\title{
Soil Solarization in a Greenhouse for Controlling Fecal Contamination
}

\author{
Shengjin WU ${ }^{1, *}$, Motoki Nishihara ${ }^{2}$, Yoshie KaWASAKI ${ }^{2}$, Akitoshi YokoYama ${ }^{2}$, Kei MatsuUra ${ }^{1}$, \\ Tomohiro KogA ${ }^{1}$, Noriko RYUdA ${ }^{1}$, Daisuke Ueno ${ }^{1}$, Koichi INOUE ${ }^{1}$ and Takashi SomeYA ${ }^{1}$ \\ ${ }^{1}$ Division of Soil Environment, Faculty of Agriculture, Saga University, Saga 840-8502, Japan \\ ${ }^{2}$ Division of Soil Science, Miyazaki Agricultural Research Institute, Sadowara-chou, Miyazaki 880-0212, Japan
}

(Received October 13, 2011; Accepted November 3, 2011)

\begin{abstract}
Contamination of agricultural soil by fecal pathogenic bacteria poses a potential risk of infection to humans. As a way of biosafety control, soil solarization in a closed greenhouse was examined for the efficiency on the inactivation of Escherichia coli which was inoculated into soil as a model microorganism for fecal pathogenic bacteria. Soil solarization greatly increased the soil temperature (depth of $15 \mathrm{~cm}$ ), which reached up to $40^{\circ} \mathrm{C}$ within the first one week of solarization, thereafter fluctuated between 40 and $46^{\circ} \mathrm{C}$ in most of the solarization periods. The population of $E$. coli in the solarized soil decreased dramatically from $10^{5} \mathrm{CFU} \mathrm{g}^{-1}$ dry soil to undetectable level $\left(<0.1 \mathrm{CFU} \mathrm{g}^{-1}\right.$ dry soil) within one week as a result, whereas $E$. coli was detected even after four weeks in the non-solarized soil in an open greenhouse. Soil solarization, however, had little effect on the total direct count and total viable count of bacteria in the soil. These results indicate that soil solarization would be useful for the rapid biosafety control of soil contaminated by human pathogens via immature compost or animal feces under greenhouse environments.
\end{abstract}

Keywords : biosafety control, Escherichia coli, manure, soil temperature

\section{INTRODUCTION}

Animal manure is commonly used as organic fertilizer in organic as well as traditional agricultural practices. However, animal manure sometimes contains some fecal pathogenic bacteria, which can be brought into soil following the land application of the contaminated manure. The fecal pathogens can survive for several weeks to several months after exposure to soil (Jiang et al., 2002; Avery et al., 2004; Islam et al., 2004b; Ohtomo et al., 2004; Nicholson et al., 2005; Unc and Goss, 2006), and get a chance to contaminate the surface of vegetables (Natvig et al., 2002; Islam et al., 2004a) and even the inner parts of the vegetable tissue (Solomon et al., 2002; Franz et al., 2007). Thus, these pathogens pose potential threats to human health.

A composting process prior to the application of the manure to the soil is generally required to decrease the risk of contamination by fecal pathogenic bacteria. However, pathogenic bacteria have occasionally been detected in compost products (Pera et al., 1991; Soares et al., 1995; Sciancalepore et al., 1996; Gong et al., 2005a, 2005b). Fecal pathogens can also be introduced into

\footnotetext{
Corresponding author: Takashi Someya, fax: +81-952-28-8777, e-mail : someyat@cc.saga-u.ac.jp

* Present address : Institute of Microbiology, Guangxi Academy of Agricultural Sciences, Nanning, Guangxi 530007, China
} 


\section{S. WU ET AL.}

the soil in other ways, including by wild animals. Therefore, it is necessary to find quick and effective measures to inactivate fecal pathogenic bacteria in soil to ensure the biosafety of agricultural soil.

Soil solarization is one of the measures which have been proven highly effective in the control of plant pathogens in soil (Lodha, 1995; Mansoori and Jaliani, 1995; Uematsu et al., 2003). Soil solarization is a way to utilize solar heating to sterilize the soil by covering the pre-irrigated soil with transparent plastic sheets, thus it has the advantages of simple manipulation and low cost. Little is known, however, about the efficiency of solarization on the control of fecal pathogenic bacteria in soil. Escherichia coli are part of the normal microbial flora of the gastrointestinal tract of humans and other warm-blooded animals. Some vero toxin-producing strains of E. coli, such as E. coli $\mathrm{O} 157$ : $\mathrm{H}$ 7, are serious pathogens and have caused food-borne infections in association with the consumption of fresh vegetables (Centers for Disease Control and Prevention, 2006). Therefore, E. coli is commonly used as an indicator of fecal contamination in the natural environment (Ishii and Sadowsky, 2008). In our previous study, it has been demonstrated that soil solarization in an upland out-door field can enhance the inactivation of E. coli (Wu et al., 2009). The aim of the present study was to evaluate the efficiency of soil solarization in inactivating fecal pathogenic bacteria in soil under greenhouse environments, by using E. coli as the modeling microorganism.

\section{MATERIALS AND METHODS}

\section{Escherichia coli strain and the culture conditions}

A non-pathogenic strain, E. coli KM1 (Wu et al., 2009), was used in the present study. E. coli $\mathrm{KM} 1$ was cultured with aeration in $10 \mathrm{~L}$ of Luria Bertani medium $\left(10 \mathrm{~g} \mathrm{~L}^{-1}\right.$ trypton, $5 \mathrm{~g} \mathrm{~L}^{-1}$ yeast extract, $10 \mathrm{~g} \mathrm{~L}^{-1} \mathrm{NaCl} ; \mathrm{pH} 7.0$ ) at $30^{\circ} \mathrm{C}$ for $24 \mathrm{~h}$ until the late exponential growth phase was reached and then re-suspended in sterile distilled water after washing three times by centrifugation $(15,000 \times g, 30 \mathrm{~min}$; Hitachi CR21, Tokyo, Japan). The cell density of E. coli in the suspension was determined by epifluorescence microscopy after ethidium bromide (EB) staining as described previously (Someya, 1995), and the E. coli cell suspension was used as the inoculum.

\section{Solar heat treatment for soil sterilization}

The soil solarization experiment was carried out in a closed greenhouse $(5.9 \mathrm{~m} \times 20 \mathrm{~m})$ for four weeks from 13 July to 10 August 2005. The experimental site was located at the Miyazaki Agricultural Research Institute $\left(32^{\circ} 01^{\prime} \mathrm{N}, 131^{\circ} 29^{\prime} \mathrm{E}\right)$, Miyazaki, Japan. The soil was a high-humic Andosols (loam). Soil from the plow layer $(5.9 \mathrm{~m} \times 16 \mathrm{~m}$, approximately top $20 \mathrm{~cm})$ was used and mixed thoroughly with the cow manure $\left(20 \mathrm{tha}^{-1}\right)$, which was contaminated artificially by adding a fresh culture of E. coli KM1. The soil was then sprinkled with water for moistening at a rate equivalent to $30 \mathrm{~mm}$ precipitation. The characteristics of the soil and cow manure are shown in Table 1. No E. coli was detected from the initial soil and cow manure. Soil solarization was achieved by covering the soil surface $\left(30 \mathrm{~m}^{2}\right)$ with transparent vinyl chloride sheets $(0.1 \mathrm{~mm}$ thickness). As a control (non-solarization treatment), $20 \mathrm{~kg}$ of soil added with contaminated manure as above was placed in a plastic container (soil depth, $20 \mathrm{~cm}$ ) without mulching in another open

Table 1 Characteristics of the soil and cow manure.

\begin{tabular}{lcccccc}
\hline \multicolumn{1}{c}{ Samples } & $\mathrm{pH}^{\mathrm{z}}$ & $\begin{array}{c}\mathrm{EC} \\
\left(\mathrm{mS} \mathrm{m}^{-1}\right)^{\mathrm{y}}\end{array}$ & $\begin{array}{c}\text { Water content } \\
(\%)\end{array}$ & $\begin{array}{c}\text { Total N } \\
\left(\mathrm{g} \mathrm{kg}^{-1}\right)^{\mathrm{x}}\end{array}$ & $\begin{array}{c}\text { Total C } \\
\left(\mathrm{g} \mathrm{kg}^{-1}\right)^{\mathrm{x}}\end{array}$ & $\begin{array}{c}\mathrm{C} / \mathrm{N} \\
\mathrm{ratio}^{2}\end{array}$ \\
\hline Soil & 5.0 & 253 & 28.0 & 5.6 & 118 & 21.1 \\
Cow manure & 8.7 & 680 & 56.9 & 22.4 & 427 & 19.1 \\
\hline
\end{tabular}

${ }^{z}$ Measured at a sample: water ratio of 1:2.5.

${ }^{y}$ Measured at a sample: water ratio of 1:5.

${ }^{x}$ Data based on dry matter. EC, electrical conductivity; N, nitrogen; C, carbon. 
greenhouse. The temperature of the soil (depth of $15 \mathrm{~cm}$ ) and the air was automatically recorded using thermometers (Temperature Datalogger, SK-L200T; Sato Keiryoki, Tokyo, Japan) at 1-h intervals throughout the experimental period. The daily average temperature as well as the daily highest and lowest temperatures was also obtained. Soil samples (each $500 \mathrm{~g}$ ) were collected randomly from five different sites at a depth of $0^{-15} \mathrm{~cm}$ in each treatment during and after soil solarization. These samples were combined, mixed thoroughly and analyzed within 2 days after sampling.

\section{A supplementary experiment}

To reveal the relationship between the air temperature and the temperature of non-solarized soil, a supplementary experiment was carried out at the same site as above from 21 October to 26 November 2008. Soil was mixed with cow manure as above, and was then placed into 3 pots $(2.1$ $\mathrm{kg}$ in each pot with depth of $20 \mathrm{~cm}$ ). The pots were kept without mulching in the open greenhouse. The temperature of the soil $(15 \mathrm{~cm}$ depth) and the air in the open greenhouse was recorded as above.

Determination of E. coli and indigenous bacteria in the soil

Each sample (10 g wet weight) was added to sterile saline $(95 \mathrm{~mL}, 0.85 \% \mathrm{NaCl})$ and homogenized at 15,000 rpm for $15 \mathrm{~min}$ in a homogenizer equipped with stainless steel blades (M-3; Nippon Seiki, Osaka, Japan). A 10-fold serial dilution was then made with sterile saline. E. coli population was determined by the plate count method using Chromocult coliform agar (Merck, Darmstadt, Germany). Sample dilutions $(100 \mu \mathrm{L})$ were plated in triplicate followed by incubation at $37^{\circ} \mathrm{C}$ for $24 \mathrm{~h}$, and the dark blue colonies of $E$. coli that developed on the plates were enumerated and the colony forming units (CFU) per gram of dry weight were calculated. Total direct count (TDC) of bacteria in the soil was determined by EB staining (Someya, 1995) and total viable count of (physiologically active) bacteria by 6-carboxy fluorescein diacetate (CFDA) staining using a modification of the procedure of Yamamoto et al. (1996). Both counts were obtained by cell enumeration under a fluorescence microscope (EFD-3; Nikon, Tokyo, Japan).

Enrichment culture for detecting E. coli

Soil samples in which E. coli was undetectable by plate counts $\left(<60 \mathrm{CFU} \mathrm{g}{ }^{-1}\right.$ dry soil) were further subjected to enrichment culture to determine whether any $E$. coli cells survived at a very low level in the soil. Each soil sample ( $25 \mathrm{~g}$ fresh weight) was placed into a flask containing 225 $\mathrm{mL}$ of lactose broth medium (Eiken, Tokyo, Japan) and incubated at $36^{\circ} \mathrm{C}$ for $24 \mathrm{~h}$. An aliquot $(100 \mu \mathrm{L})$ of the culture was inoculated onto Chromocult coliform agar to examine the presence of E. coli.

The detection limit of the enrichment culture was estimated to be $0.04 \mathrm{CFU} \mathrm{g}^{-1}$ fresh soil

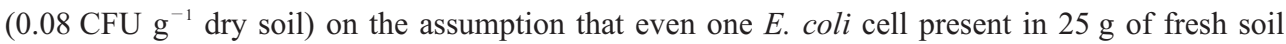
could cause a positive reaction after the enrichment.

\section{Statistical analysis}

The means and the standard deviations of the CFU were determined from triplicate plates for each dilution of the samples. For microscopic counts, the means and standard deviations of the bacterial counts were obtained from triplicate filters of each sample and 10 microscopic fields of each filter were subjected to bacterial counts. The significance of the differences among means was evaluated using the one-way ANOVA followed by Fisher's least significant difference (LSD) test.

\section{RESULTS}

\section{Temperature of the soil and air during solarization}

Changes in the daily temperature during the experimental period are shown in Fig. 1. In the open greenhouse (control treatment), the daily average and highest air temperature were around 


\section{S. WU ET AL.}

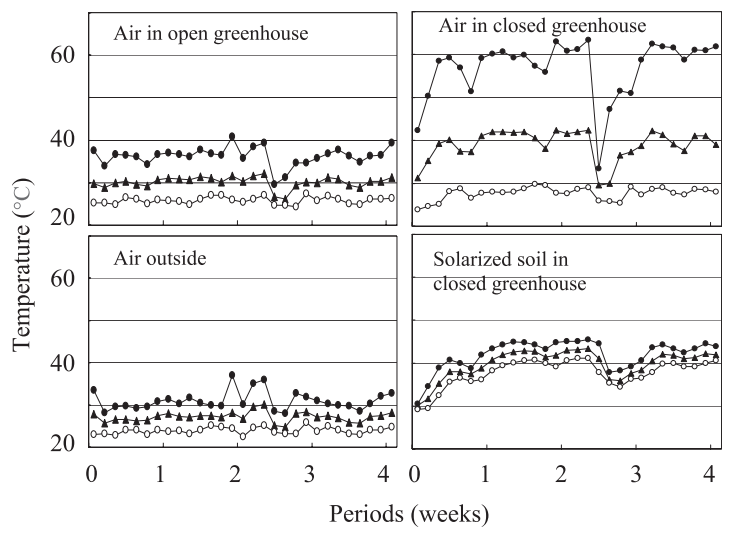

Fig. 1 Changes in the daily highest $(\mathbf{O})$, average $(\mathbf{\Delta})$ and lowest $(\bigcirc)$ air temperatures in out-door, an open and a closed greenhouse, and soil temperatures in a closed greenhouse.

$30^{\circ} \mathrm{C}$ and $36^{\circ} \mathrm{C}$, respectively. In the closed greenhouse where soil solarization was performed, the daily average air temperature was around $40^{\circ} \mathrm{C}$, which was $10^{\circ} \mathrm{C}$ higher than that of the open greenhouse; the daily highest temperature ranged between $55^{\circ} \mathrm{C}$ to $64^{\circ} \mathrm{C}$, about $20^{\circ} \mathrm{C}$ higher than that of the open greenhouse in most of the period except several successive rainy days. Outside of the greenhouse, the daily average air temperature was around $27^{\circ} \mathrm{C}$ throughout the period, and the daily highest air temperature was mostly between $28^{\circ} \mathrm{C}$ to $34^{\circ} \mathrm{C}$. In the solarized soil at a depth of 15 $\mathrm{cm}$, the daily average temperatures increased to more than $40^{\circ} \mathrm{C}$ within the first one week, and kept at above $40^{\circ} \mathrm{C}$ thereafter except several successive rainy days when soil temperature decreased down to $35^{\circ} \mathrm{C}$. The daily highest temperature was between $40^{\circ} \mathrm{C}$ to $46^{\circ} \mathrm{C}$ in most of the period.

It failed to record the temperature of non-solarized soil placed in the open greenhouse due to the malfunction of a data logger. In the supplementary experiment, however, it was found that the average temperature of non-solarized soil was in a good linear regression $\left(y=x+0.345, R^{2}=\right.$ 0.9636) with the average air temperature in the greenhouse (Fig. 2). Therefore, it could be deduced that in the soil solarization experiment, the daily average temperature of the non-solarized soil was around $30.3^{\circ} \mathrm{C}$, which was ca. $10^{\circ} \mathrm{C}$ lower than that of the solarized soil.

Effect of solarization on the survival of E. coli and indigenous bacteria in the soil

The changes in the number of $E$. coli in the soil during the solarization experiment are shown in Fig. 3. The abundance of E. coli in the soil samples in all treatments was approximately $2 \times 10^{5}$ $\mathrm{CFU} \mathrm{\textrm {g } ^ { - 1 }}$ dry soil at the beginning of the experiment. The number of E. coli decreased rapidly and became undetectable even by enrichment culture $\left(<0.08 \mathrm{CFU} \mathrm{\textrm {g } ^ { - 1 }}\right.$ dry soil $)$ after one week in the solarized soil. In contrast, in the non-solarized soil, the number of $E$. coli decreased slowly and remained at a level of approximately $10^{2} \mathrm{CFU} \mathrm{g}{ }^{-1}$ dry soil after 2 weeks, and was even detectable by enrichment culture after 4 weeks. These results suggest that soil solarization is effective in the rapid inactivation of $E$. coli in soil.

The changes in the number of soil indigenous bacteria are shown in Fig. 4. TDC of bacteria was approximately $1.0 \times 10^{10}$ cells $\mathrm{g}^{-1}$ dry soil at the beginning of the experiment and no significant change $(P>0.05)$ was observed throughout the experiment. Total viable count of soil bacteria was approximately $2.0 \times 10^{9}$ cells $\mathrm{g}^{-1}$ dry soil initially and then decreased down to approximately 1.0 $\times 10^{9}$ cells $\mathrm{g}^{-1}$ dry soil within the first week, thereafter kept at this level over the experimental period. There was no significant difference $(P>0.05)$ between the solarized and non-solarized treatments in either the TDCs or total viable counts. These results suggest that solarization has little effect on either total or physiologically active bacteria in soil. 


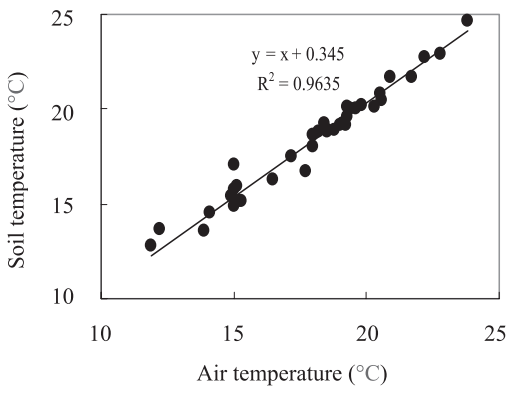

Fig. 2 Relationship between the average temperatures of the non-solarized soil and the air in an open greenhouse in a supplementary experiment.

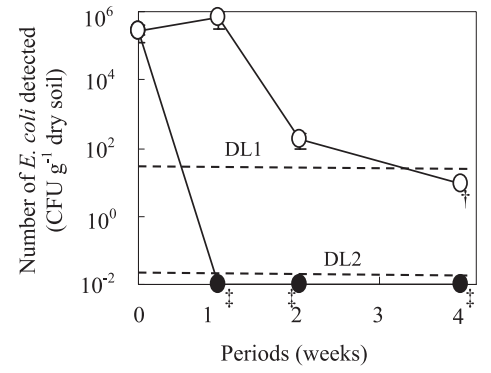

Fig. 3 Changes in the number of Escherichia coli in the solarized soil ( ) and in the non-solarized soil $(\bigcirc)$ during the experiment. DL1, detection limit of the plate counts (60 CFU g ${ }^{-1}$ dry soil); DL2, detection limit of the enrichment culture (0.08 CFU $\mathrm{g}^{-1}$ dry soil). Error bars indicate standard deviation $(n=3)$. $\dagger$, Not detected by the plate counts; $\$$, Not detected by the enrichment culture.

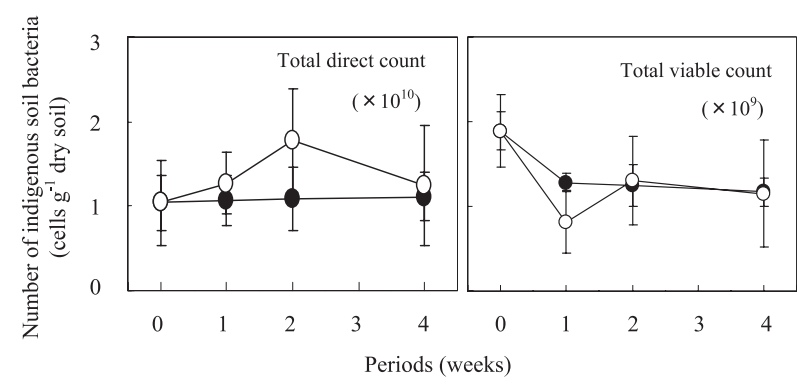

Fig. 4 Changes in the number of indigenous soil bacteria in the solarized $(\bigcirc)$ and non-solarized $(\bigcirc)$ soil.

\section{DISCUSSION}

It has been reported that soil solarization during the hot summer season is effective in reducing the population of soil-borne plant pathogens (Lodha, 1995; Mansoori and Jaliani, 1995). Our previous study has shown that soil solarization in an outdoor upland field was also effective in inactivating the fecal indicator bacterium E. coli in soil within 4 weeks (Wu et al., 2009). The present study showed that soil solarization in a closed greenhouse was much more effective for controlling fecal pathogens, as it inactivated $E$. coli in soil within one week.

The inactivation of $E$. coli in the solarized soil might be mainly attributed to the higher soil temperature caused by the solarization. In our previous experiment in an outdoor upland field, the average temperature was raised up to $35^{-} 38^{\circ} \mathrm{C}$ in the solarized soil, compared with about $28^{\circ} \mathrm{C}$ in the non-solarized soil, and E. coli was inactivated in the former within 4 weeks but survived for more than 6 weeks in the latter (Wu et al., 2009). In the present study, higher soil temperature (around $40^{\circ} \mathrm{C}$ ) was obtained by performing the soil solarization in a closed greenhouse, resulting in the inactivation of $E$. coli within one week. While in the non-solarized soil in the open greenhouse, soil temperature was deduced to be around $30^{\circ} \mathrm{C}$, and $E$. coli was still detectable within 4 


\section{S. WU ET AL.}

weeks. The average temperature of outside air was about $27^{\circ} \mathrm{C}$ in the present study (Fig. 1), similar to that in the upland field experiment. It is obvious that soil solarization could cause higher soil temperature thus be more effective in inactivating $E$. coli in soil in a greenhouse than in outdoor field.

Soil solarization had little effect on the population of total bacteria and viable bacteria in soil in this study (Fig. 4). These results suggest that indigenous soil bacteria are adaptable to the changes in soil temperature observed during the experiment, and can maintain their activity even under the solarization treatment. In contrast, the $E$. coli population decreased gradually after exposure to the soil environment even without soil solarization, suggesting that $E$. coli is susceptible to stress factors in soil. Competition of indigenous soil bacteria and predation by protozoa may play important roles in the inactivation of $E$. coli in soil. Indigenous soil bacteria can compete for nutrient and some of them can be antagonistic by producing antibiotics or toxic substances, thus suppress introduced bacteria (Acea et al., 1988). Protozoa also can behave as suppressors of bacteria in soil (Clarholm, 1981), although their contribution to grazing on human pathogens is still unclear.

In conclusion, soil solarization in a closed greenhouse during summer in the southern part of Japan was effective in raising the soil temperature to $>40^{\circ} \mathrm{C}$, resulting in the rapid inactivation of $E$. coli introduced into the soil. Therefore, soil solarization would be useful in soil biosafety control.

The authors are grateful to Dr. Tomoyoshi Hashimoto, National Agricultural Research Center for Kyushu Okinawa Region (present address: National Agricultural Research Center), for his kind advice and technological guidance. This work was partially supported by the Research Project (No. 1657) for Utilizing Advanced Technologies in Agriculture, Forestry and Fisheries funded by the Ministry of Agriculture, Forestry and Fisheries of Japan.

\section{REFERENCES}

Acea, M. J., Moore, C. R., Alexandaer M. 1988. Survival and growth of bacteria introduced into soil. Soil Biol. Biochem. 20: 509-515.

Avery, S. M., More, A., Hutchison, M. L. 2004. Fate of Escherichia coli originating from livestock feces deposited directly onto pasture. Lett. Appl. Microbiol. 38: 355-359.

Centers for Disease Control and Prevention. 2006. Ongoing multistate outbreak of Escherichia coli serotype O157: H7 infections associated with consumption of fresh spinach-United States, September 2006. MMWR, 55: 1-2. (http://www.cdc.gov/mmwr/preview/mmwrhtml/mm55d926a1.htm)

Clarholm, M. 1981. Protozoan grazing of bacteria in soil-impact and importance. Microb. Ecol. 7: 343-350.

Franz, E., Visser, A. A., van Diepeningen, A. D., Klerks, M. M., Termorshuizen, A. J., van Bruggen, A. H. 2007. Quantification of contamination of lettuce by GFP-expressing Escherichia coli O157: H7 and Salmonella enterica serovar Typhimurium. Food Microbiol. 24: 106-112.

Gong, C. M., Inoue, K., Inanaga, S., Udou, T., Someya, T. 2005a. Survival of pathogenic bacteria in compost with special reference to Escherichia coli. J. Environ. Sci. 17: 770-774.

Gong, C. M., Koshida, J., Moriyama, N., Wang, X., Udou, T., Inoue, K., Someya, T. 2005b. Occurence and survival of coliform bacteria, Escherichia coli and Salmonella in various manure and compost. (Japanese text with English abstract) Jpn. J. Soil Sci. Plant Nutr. 76: 865-874.

Ishii, S., Sadowsky, M. J. 2008. Escherichia coli in the environment: Implications for water quality and human health. Microbes Environ. 23: 101-108.

Islam, M., Dole, M. P., Phatak, S. C., Millner, P., Jiang, X. 2004a. Persistence of enterohemorrhagic Escherichia coli O157: $\mathrm{H} 7$ in soil and on leaf lettuce and parsley grown in fields treated with contaminted manure composts or irrigation water. J. Food Prot. 67: 1365-1370.

Islam, M., Morgan, J., Dole, M. P., Phatak, S. C., Millner, P., Jiang, X. 2004b. Fate of Samlmonella enterica serovar Typhimurium on carrots and radishes grown in fields treated with contaminated manure compost 


\section{GREENHOUSE SOIL SOLARIZATION}

or irrigation water. Appl. Environ. Microbiol. 70: 2497-2502.

Jiang, X. P., Morgan, J., Doyle, M. P. 2002. Fate of Escherichia coli O157: H7 in manure-amended soil. Appl. Environ. Microbiol. 68: 2605-2609.

Lodha, S. 1995. Soil solarization, summer irrigation and amendments for the control of Fusarium oxysporum f. sp. Cumini and Macrophomina phaseolina in arid soils. Crop Protection 14: 215-219.

Mansoori, B., Jaliani, N. K. H. 1995. Control of soilborne pathogens of watermelon by solar heating. Crop Protection 15: 423-424.

Natvig, E. E., Ingham, S. C., Ingham, B. H., Cooperband, L. R., Roper, T. R. 2002. Salmonella enterica serovar Typhimurium and Escherichia coli contamination of root and leaf vegetables grown in soil with incorporated bovine manure. Appl. Environ. Microbiol. 68: 2737-2744.

Nicholson, F. A., Groves, S. J., Chambers, B. J. 2005. Pathogen survival during livestock manure storage and following land application. Bioresour. Technol. 96: 135-143.

Ohtomo, R., Minato, K., Saito, M. 2004. Survival of Escherichia coli in a field amended with cow feces slurry. Soil Sci. Plant Nutr. 50: 575-581.

Pera, A., Vallini, G., Frassinetti, S., Cecchi, F. 1991. Co-composting for managing effluent from themophilic anaerobic digestion of municipal solid waste. Environ. Technol. 12: 1137-1145.

Sciancalepore, V., Colangelo, M., Sorlini, C., Ranalli, G. 1996. Composting of effluent from a new twophases centrifuge olive mill: Microbial characterization of the compost. Toxicol. Environ. Chem. 55: $145^{-}$ 158.

Soares, H. M., Cardenas, B., Weir, D., Switzenbaum, M. S. 1995. Evaluating pathogen multiplication in biosolids compost. Biocycle 36: 70-72.

Solomon, E. B., Yaron, S., Matthews, K. R. 2002. Transmission of Escherichia coli O157: H7 from contaminated manure and irrigation water to lettuce plant tissue and its subsequent internalization. Appl. Environ. Microbiol. 68: $397-400$.

Someya, T. 1995. Three-dimensional observation of bacteria in organic debris with a confocal laser scanning microscope. Soil Microorganisms 46: 61-69.

Uematsu, S., Nishi, K., Kita, N. 2003. Hot water soil sterilization begins in Japan. Farming Japan 37: 35-41.

Unc, A., Goss, M. J. 2006. Culturable Escherichia coli in soil mixed with two types of manure. Soil Sci. Soc. Am. J. 70: 763-769.

Wu, S., Nishihara, M., Kawasaki, Y., Yokoyama, A., Matsuura, K., Koga, T., Ueno, D., Inoue, K., Someya, T. 2009. Inactivation of Escherichia coli in soil by solarization. Soil Sci. Plant Nutr. 55: 258-263.

Yamamoto, H., Hashimoto, Y., Ezaki, T. 1996. Study of non-culturable Legionella pneumophila cells during multiple-nutrient starvation. FEMS Microbiol. Ecol. 20: 149-154. 